Paideusis

\title{
The Pedagogy of Suffering: Four Fragments
}

\section{David W. Jardine, Graham McCaffrey and Christopher Gilham}

Volume 21, Number 2, 2014

\section{Working Compassion}

URI: https://id.erudit.org/iderudit/1071561ar

DOI: https://doi.org/10.7202/1071561ar

See table of contents

Publisher(s)

Canadian Philosophy of Education Society

ISSN

0838-4517 (print)

1916-0348 (digital)

Explore this journal

Cite this article

Jardine, D., McCaffrey, G. \& Gilham, C. (2014). The Pedagogy of Suffering: Four Fragments. Paideusis, 21(2), 5-13. https://doi.org/10.7202/1071561ar

\section{Article abstract}

This paper is a collection of small, formal and informal writings and is part of the early groundwork we have been doing together on the topic of the pedagogy of suffering, a phrase that has certainly given pause to many colleagues we have spoken to. We are trying to understand and articulate how and why suffering can be pedagogical in character and how it is often key to authentic and meaningful acts of teaching and learning. We are exploring threads from both the hermeneutic tradition and from Buddhism, in order to decode our understandable rush to ameliorate suffering at every turn and to consider every instance of it as an error to be avoided at all costs. We also look to these traditions to begin to formulate how a pedagogy that turns away from suffering suffers a great loss, and how a pedagogy that turns towards suffering can become a locale of great teaching and learning, great wisdom and grace. (c) David W. Jardine, Graham McCaffrey, Christopher Gilham, 2014

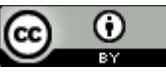

This document is protected by copyright law. Use of the services of Érudit (including reproduction) is subject to its terms and conditions, which can be viewed online.

https://apropos.erudit.org/en/users/policy-on-use/ 


\title{
The Pedagogy of Suffering: Four Fragments
}

\author{
DAVID W. JARDINE \\ University of Calgary
}

GRAHAM McCAFFREY

University of Calgary

CHRISTOPHER GILHAM

St. Francis Xavier University

\begin{abstract}
This paper is a collection of small, formal and informal writings and is part of the early groundwork we have been doing together on the topic of the pedagogy of suffering, a phrase that has certainly given pause to many colleagues we have spoken to. We are trying to understand and articulate how and why suffering can be pedagogical in character and how it is often key to authentic and meaningful acts of teaching and learning. We are exploring threads from both the bermeneutic tradition and from Buddhism, in order to decode our understandable rush to ameliorate suffering at every turn and to consider every instance of it as an error to be avoided at all costs. We also look to these traditions to begin to formulate how a pedagogy that turns away from suffering suffers a great loss, and how a pedagogy that turns towards suffering can become a locale of great teaching and learning, great wisdom and grace.
\end{abstract}

\section{Introduction}

These small, formal and informal writings are part of the early groundwork we have been doing together on the topic of the pedagogy of suffering, a phrase that has certainly given pause to many colleagues we have spoken to. We are trying to understand and articulate how and why suffering can be pedagogical in character and how it is often key to authentic and meaningful acts of teaching and learning. This is an ancient idea from the Greek tragedies of Aeschylus (c. 525 BCE) - pathei mathos or "learning through suffering." We are exploring threads from both the hermeneutic tradition and from Buddhism, in order to decode our understandable rush to ameliorate suffering at every turn and to consider every instance of it as an error to be avoided at all costs. We also look to these traditions to begin to formulate how a pedagogy that turns away from suffering suffers a great loss, and how a pedagogy that turns towards suffering can become a locale of great teaching and learning, great wisdom and grace.

We come to this work from differing personal and professional locales, working as we do with teachers and student teachers, nurses and student nurses, educational administrators and medical personnel, patients and school children. We also work with the rubrics and regimes of mental health, "coded" children, Ministry of Education and School Board mandates, the pleas of parents of sick children or troubled children or children upon whom all the urgencies and distractions of modern life are sometimes brought to bear. We live

(C) Copyright 2014. The author, David W. Jardine, Graham McCaffrey \& Christopher Gilham, assigns to Paideusis the right of first publication and educational and non-profit institutions a non-exclusive license to use this document for personal use and in courses of instruction provided that the article is used in full and this copyright statement is reproduced. Any other usage is probibited without the express permission of the author. 
and work, too, with teachers and students caught in the rushes, exhaustions and panics of day-to-day school life and work.

Both hermeneutics and Buddhism teach us that patience and practice are great virtues in these locales, and they also both teach, in related by different ways, that suffering is one of the indigenous inhabitants of these life-worlds, one that needs befriending, commiseration, compassion and understanding.

But, as is common knowledge, these locales sometimes seem, these days, to be full of nothing but emergencies. And, as Wendell Berry (with Moyers, 2013) has eloquently said, "the situation you're in is a situation that is going to call for a lot of patience, and to be patient in an emergency is a terrible trial." And, for the sake of ameliorating the looming immediacy of this insight into the situation we're in - what HansGeorg Gadamer (1989, p. xxii), described as the "naive self-esteem of the present moment"- we cite from a text composed by Tsong-kha-pa in 1406, a time also described therein as one full of emergency: "it is very crucial that you generate the patience that accepts suffering" (2004, p. 172-173). Patience, in this text, is considered one of the Great Perfections (Sanskrit: paramita).

What follows are some first steps in our efforts to accept this trial. Readers will find that these fragments drift in their use of "I" and "we"; they cleave to academic forms and then move into flits of email conversations, with dates and times and authors' initials, with inserted ellipses or sentence fragments. We have left, too, certain clusters of nearly impenetrable dives into philosophical depths that have surely outplayed us. We have left some of this as reminders of the lives lived underneath the veneers of scholarship, as a gift to the heartbreakingly unfinished character of our work.

\section{Fragment One: Breaking the Gaze}

To have an orientation to the world...means to keep oneself so free from what one encounters of the world that one can present it to oneself as it is. To rise above the pressure of what impinges on us from the world means to have language and to have 'world.' (Gadamer 1989, p. 444)

This is why hermeneutics is interested in "what happens to us over and above our wanting and doing" (Gadamer, 1989, p. xxviii). It wants to break this spell of being spellbound by wanting and doing in favor of a glimpse into what happens to us and the work that glimpse requires. For the world to present itself to us "as it is" means that what we can know and experience of the world doesn't just rise up in the immediacies of my responses to it and experiences of it. Experience and knowledge need not be enslaved to the presumptions of constructivism where I can only make the world in my own image. With practice, the world can start to "stand there," unlinked to my wanting and doing, unlinked to my worry or fret, and can be experienced in a way that is more real than my fret allows.

Often, our deeply human, deeply animal responses to the impingement of the world involve a sort of panicky retreat from a sense of threat. The deepest consequence of such retreats, so suggests Tsong-kha-pa (2002, p. 120), is what he calls a "reifying view" wherein the thing that rises up in response to such impingements becomes taken falsely to be a self-existent object. In this cycle, another, correlative reification begins that seems to indicate that I, too, am a self-existent "myself" now caught in a death-throe battle with this "other." This (however contingently and occasionally understandable and warrantable) double root response is the root of suffering itself because it presumes henceforth that there is some permanent object commensurate with our panic about our own frailty, and then sets off the futile pursuit of grasping at straws.

This reifying response is codified in the concept of substance and it is this concept that is the locale of both hermeneutic and Buddhist critique and contemplation.

"There is no truth in our substance" (from St. Jerome's [c. 347-420] commentary on the Psalms [1964, p. 283]). "The concept of substance is...inadequate for historical being and knowledge. [There is a] radical challenge to thought implicit in this inadequacy" (Gadamer, 1989, p. 242). The radical challenge to thought entails breaking this duplicitous spell - "break[ing] open the being of the object" (p. 362) - understanding things to be something other than permanent, self-existing substances. And therefore likewise breaking open the being of the one experiencing that object that stands there now broken open - coming to understand 
myself to be something other than a permanent self. Hermeneutic experience requires the long and difficult work of stepping out of this duplicity and coming to experience myself and the object of my experiences as "dependently co-arising" (in Buddhist language, from the Sanskrit, pratitya-samutpada) and therefore mutually empty (shunya) of self-existence (svabhava).

Hans-Georg Gadamer (1989) calls this "a hitherto concealed experience that transcends thinking from the position of [a] subjectivity" (p. 100) caught up in the spell of its own wanting and doing. This spell "is a delusion; ignorance mistakenly superimposes upon things [both the self and the objects that that self experiences] an essence that they do not have. It is constituted so as to block perception of their nature. It is a concealer." (Tsong-kha-pa, 2002, p. 208). He also contends that being caught in the spell of wanting and doing gives rise to "an attitude of hostility driven by a reifying apprehension of the characteristics of the causes of harm ["impingement'] and the phenomena related to them" (Tsong-kha-pa, 2000, p. 225).

In Buddhism, this cycle gives rise to impatience (Tsong-kha-pa, 2000, p. 225), that gives rise to further hostility, further concealment of the dependent co-arising of these phenomena, further entrenchment in the presumed protectiveness of self-existence, and so on. This is why Buddhism characterizes the life-world as a Wheel.

But both hermeneutics and Buddhism suggest that one can become practiced at breaking this spell:

The more you practice these things, the more accustomed your mind will become to them, and the easier it will be to practice what you had initially found difficult to learn. You will have visions of the Buddha day and night. (Tsongkhapa, 2000, p. 185-186)

One of the key locales of our panicky, reifying retreat from the vertigo experience of the dependent co-arising of the world, is the fear of one's own impermanence and the impermanence of the world - this is what is most deeply "concealed." This experience of finitude (an experience that is central to hermeneutics) is a key cause of panic and retreat and retrenchment into feigned and delusional grasping at and subsequent attachments to a permanent self and a permanent world and all the vainglorious pursuits that then ensue. In the face of glimpsing the suffering of the world and ourselves - instead of experiencing the life-world "as it is" - we easily induce a whole new layer of delusion to prevent or conceal this realization, thus causing our suffering to become insufferable. We then start looking for the cure of suffering within the very falsehoods and forgetfulness that keep it in place.

One common manifestation of this mechanism of delusional retreat is that of anger, one of my own terribly familiar consorts whose dance I've deviled far too often and easily.

So here is the tangle and another meager effort at untangling it all over again. (I need to remember that "the more you practice these things, the more accustomed your mind will become to them" refers both to falling for this anger-cycle and to the work of breaking this spell; it refers equally, also, to cycles of pleasure and joy).

Anger entails being caught in the gaze of the very thing that is the object of anger. It is this persistent gaze that then codifies that object, strengthens it. It is strengthened by my anger, and condoned by all the furious attention I cede to it. It feeds on my attention to it. It seeks out my attention, lures it, and adores it, and the more I falsely reify it into something self-existing, the more its gravity (its draw and its seriousness) increases. The more real it appears and therefore the more real and more justified is my anger towards it. I might falsely believe that my negative attention towards it will dissipate its hold, but it does not.

With my attention, it rises up, and then I rise up, again, to meet that rising.

I thus suffer it under a certain forgetting of my duplicity in its reality and I blame it for my increasing arousal and anger at its existence. Thus my forgetting (Lethe) becomes lethal because I seek a relief to this suffering only within this complicity. My desire to be the winner in and of this battle only deepens the trench.

Only by freeing myself from this cycle of mutual admiration (it really is admiration; I love my anger sometimes, it can make me feel alive and righteous) can I see it for what it $i s$, and out from under the aroused distortions of my complicity in it, and the ways I've been "had" by this cycle. I can begin, however fleetingly and frailly and circumstantially, to feel compassion. I can begin to feel its suffering, not simply "my" suffering at its hands ("If only it would stop, I would stop!" Hah!). Feeling compassion does not mean condoning. It means seeing it for what it is - a fleeting and impermanent flight of causes and conditions whose fleetingness 
and impermanence can now be interpreted and unraveled. It is now no longer a "game" we need to let "play" with us (for it will surely outplay us [see Gadamer, 1989, p. 106]), but an inheritance (Gadamer, 1994, p. 192) that we can now strive to understand and begin to free ourselves from through such insight. By freeing ourselves from it, we free ourselves for it. We can now think and act out of love for this suffering. What changes is not that the world is now finally and fully "cured." What changes is our attachment to and investment in that incurable world, and our ability, for the sake of ourselves and others, to speak about such alluring attachment and the blindness and suffering that it causes.

\section{Fragment Two: Thoughts on "Breaking the Gaze"}

CG: Monday, August 5, 2013 9:14 am: "The deepest stream of our deeply human, deeply animal responses to this impingement is a sort of panicky retreat from a sense of threat" or the face to face fight so common with the students I've worked with - who are also at once, the leukemia patient Graham wrote about. (McCaffrey, in press).

Or is paralysis, too, a response?

I wonder if the root of suffering is necessarily a first and natural response that is, with practice, caught early on and seen for what it is. In other words, the initial response of impingement-suffering might be necessary for the cultivation of the ability to distance and see one within that cycle. Without this noticing practice the subsequent attachment to the cycle is unnecessary suffering but not the root of suffering.

Kearney's reference to interpretive work or hermeneutics as involving Joyce's two minds (Kearney, 2011) rings a bell here, and serves as another connection to this piece you wrote David. Perhaps with practice we can almost instantly have two minds about situations and one of them is always initiated as an impingement or suffering...only once we catch what was thrown can we put language to it in such a way that it is livable. Not sure if my distinction is distinct enough to be clear but this is, anyhow, how it seems to be for me. Perhaps a sign of my own need for ongoing practice. I always seem to suffer at least a twinge of single-mindedness (sometimes as the inner voice of "f\%\#\& you!") but sometimes can catch myself and have that fuller mind or mindfulness or that reposing. Seems to me the paper does say this too...the breaking open is needed...if not, then one tries to evade suffering altogether and the logic of a search for cure through mindfulness is at play.

In other words, the initial impingement can be both necessary and sufficient condition for either further suffering or livability with suffering, if that makes sense.

"We then start looking for the cure of suffering within the very falsehoods and forgetfulness that keep it in place." The falsehood of behaviorist strategies (I really like Graham's [in press] take on this. The term is "utterly over-determined") to ameliorate suffering are based on the reality of self-existence, that is, the problem is inherent to the child. No wonder, as you both pointed out, vituperation amplifies among some students and patients, as if to say to oneself and others "It's not me" or "It's not just me." And also, there are reasons for this anger and they depend on the world and not just issuances from my own battered ego.

Your comment on practice as possibility for both repeating the cycle or getting out of it really hits home with my experiences. This reminds me of one student I had in my special education classroom who did pretty much everything to get us to respond to his anger in kind. We locked down the school and removed the rest of the kids from the classroom - he was a big fella - and he destroyed our classroom. We dodged a few desks and chairs but he never came at me or the counselor in the room. We worked hard to keep our distance and stay calm and show compassion for his anger. He screamed and yelled and called us names. He was desperate for us to enter the cycle and feed it. Alas when we did not and he was exhausted, he collapsed and whimpered on the floor. The tough guy image he held for so long shattered because we broke the gaze for him, in that instance. He was so used to having his family and other people respond in kind that his suffering was reinforced and expected and actually sought after.

Some would claim that the biochemistry of his brain was wired to seek those pathways and chemical feeds that arise from escalation, that the escalation cycle releases endorphins that are addictive and thus reinforce the ways people are. 
I have come to believe that in education the "inner" forms of knowing derived from talking about and being with phenomenon are reified so much that it becomes all there is and conceals the complex fabric of life together. It's so much easier to say "It's his brain doing it."

DJ: Monday, August 5, 2013 8:29 pm: Yep, Chris, I think this is exactly right. First of all, yes, yes, yes, "the inner voice of ' $\mathrm{f} \%$ $\%$ you'" sounds, gulp, vaguely familiar to me! And all the "meds" I've flirted with don't replace the work of catching that when it arises, stopping, settling. Practice! Tough.

And that "big fella" you talked about - the anger, like, perhaps, the anger of Graham's leukemia patient - comes after and is built upon that "inner reification" into a threatened self, and the anger intensifies and deepens that reification, making it feel more and more embattled. And then all this gets masked, concealed with ensuing arguments and fights over the "object" of the anger itself.

"In education, the inner stuff... is reified" - this is really important, because our students often come to us already closed, already encased. My belief has always been that teaching is a gesture of trying to open this encasement. Not just "keeping ourselves open" to the world but also, as Mircea Eliade (1968, p. 139) put it, "keeping the world open." That what seems to be simply an object that is what it is, is, rather, interpretable, openable, untangle-able. That is why yours and the counselor's "calm" and "patience" becomes so important, because if there is no open, free space (Gadamer, 1986, p. 59; see Jardine, 2012, pp. 1-8) in the world, there is no "where" for an embattled and encased life to open out into, so to speak.

I always think of that wonderful passage from Chogyam Trungpa (2003):

Meditation should reflect a mentality of richness in the sense of using everything that occurs in the state of mind. Thus, if we provide enough room for restlessness so that it might function within the space, then the energy ceases to be restless because it can trust itself fundamentally. Meditation is giving a huge, luscious meadow to a restless cow. The cow might be restless for a while in its huge meadow, but at some stage, because there is so much space, the restlessness becomes irrelevant. (pp. 218-219)

Our natural tendency tends to be zooming in on these troubles when they arise, narrowing the spaciousness, thus increasing the sense of encasement in an embattled self. We all then end up panicking in an emergency and blaming the cow or its brain chemistry.

In this regard, the "brain" stuff is as pernicious, potentially, as the OCD or ADHD labeling, which simply gives that inner reification a reality that is - again, to use Graham's term - utterly over-determined. Then we end up with arguments about whether this or that is the correct over-determined term that corresponds to the self-existence "condition" that further suppress that first gesture of reification-under-threat.

The first gesture, in Buddhism, isn't the fight. It is the first retraction into some embattled sense of myself that therefore needs to be fought for, protected, or "cured." Big fella might have felt that "there is no way out," (no "luscious meadow," you might say) which simply amplifies the delusion of self-existent encasement. That's why anger "itself" isn't the issue, exactly.

This is why, in an oversimplified way, ignorance of our lot is placed as the Second Noble Truth after the truth of suffering as the root afflictive cause of suffering. Not just any ignorance: ignorance precisely of the emptiness of that falsely reified self that doesn't need the battle. Such battles simply mask something and makes the mask more and more masking - it "conceals the complex fabric of life together"...nice phrase.

This thing you noted about the collapse and exhaustion. These are really interesting words. Tsongkha-pa and the boys talk about burning off one's afflictions, about, shall we say, "exhausting" them. This, I guess, is why hermeneutics is a practice and not a method, exactly, because "breaking open" is an arduous, repeated thing. We encounter reifications over and over again and have to take up the task of interpretation in concert with these arisings.

\section{Fragment Three: Bringing Suffering into the Path}

You must accept [suffering] when [it] arise[s] because (1) if you do not do this, in addition to the basic suffering, you have the suffering of worry that is produced by your own thoughts, 
and then the suffering becomes very difficult for you to bear; (2) if you accept the suffering, you let the basic suffering be and do not stop it, but you never have the suffering of worry that creates discontentment when you focus on the basic suffering; and (3) since you are using a method to bring even basic sufferings into the path, you greatly lessen your suffering, so you can bear it. Therefore, it is very crucial that you generate the patience that accepts suffering. (Tsong-kha-pa, 2004, pp. 172-3)

This passage is from Volume Two of Tsong-kha-pa's The Great Treatise on the Stages of the Path to Enlightenment and it reminds me of something we have been skirting around since we started our venture: that there is an admixture in our relationship to suffering. We wish to turn towards it and ameliorate it without denying it, suppressing it or lying to ourselves about it. Amelioration is not the same as eradication - to "let the basic suffering be."

We want, therefore, to "bring it into the path" (of interpretation, of meditation, of practice), that is, to use the Greco-European formulation, we want to see the good in it and not simply recoil away from its appearances.

As you continually experience... suffering...you absolutely must know how to bring it into the path. Otherwise...you either generate hostility [one source and result of the very reification that leads to further suffering - see above] or you become discouraged about cultivating the path, either circumstance interfering with applying yourself to virtue" (Tsong-kha-pa, 2004, p. 172).

When the First Noble Truth states that all life is suffering, accepting this truth and learning to be patient with its endless reappearance in our lives and the lives of our students, clients, patients, etc., prevents the arising of a sort of "secondary suffering" that is based on worrying about this "primary" or "basic" suffering, becoming frantic or impatient in relationship to it, complicating it with overlays of anxiety, anger, or resentment, as well as overlays of well-meaning sympathies, optimism, promises of cures, interventions, or schemes of facilitation in its weakest senses (attempts to "make things facile/easy").

This idea of "let[ting] the basic suffering be" is an interestingly phenomenological move, similar to Martin Heidegger's (1963, p. 58) tortuous formulation: "'phenomenology' means...to let that which shows itself be seen from itself in the very way in which it shows itself from itself." He continues by asking "What is it that phenomenology is to 'let us see'?" (p. 59):

Manifestly, it is something that proximally and for the most part does not show itself at all: it is something that lies bidden . . . but at the same time it is something that belongs to what thus shows itself. That which remains bidden in a egregious sense, or which relapses and gets covered up again, or which shows itself only 'in disguise', is not just this entity or that, but rather the Being of entities. (p. 59)

To the extent that hermeneutics proceeds to identify this Being of entities with impermanence, dependent coarising, historicity, finitude, and the enduring or suffering/undergoing/venturing of experience (Erfahrung, which is linked by Gadamer [1989, p. 356] to pathei mathos, and linked, in his work, to a sense of possible Sangha/refuge in his elaborations of the term Vorfabren, "ancestors"/lineage), this passage is rich and full and useful for our purposes. Heidegger is talking back, here, to his own teacher, Edmund Husserl (1970, p. 178), and the latter's attempts, through the eidetic reduction to "fix [the life-world] once and for all." What is hidden, covered up, and in disguise in such a move is the basic suffering of the world - Being in a deeply temporal and finite sense, unlinked to substance and its delusional desires.

The recognition of basic suffering often relapses into hiddenness under regimes of cure. The basic difficulty in, for example, coming to learn to read, is masked or disguised by the promises of reading programs designed to make it easy, as if its basic suffering is not actually basic but just an error that can be eradicated through technical means. The basic suffering still appears, but now only "in disguise" and the guise is not seen through and we become entranced by the guise and caught in the false promises of the 
various "cover ups." We then find ourselves suffering the ever-accelerating rush to find the right disguise to put our minds at ease. Wheeling.

\section{Fragment Four: "And Yet, and Yet"}

DJ: If I may, attached are two poems written by Judson Innes. I think both of these pieces are absolutely brilliant and breathtaking, and they linger nearby our topic in ways that I find illuminating. In one, "Time," (Innes, in press a) we get a "fell swoop and talon strike. / A mere moment swept away, devoured." And in the other, "A Pocketful of Darkness" (in press b), we're left to "Call up to the creators - "we are here, we are here." Two lovely things that give a lilt to the voice of suffering. They remind me of the last two lines of Don Domanski's (1998) poem "Owl", full of a giddiness and sudden shadow, "the spirits of bears lift the trees / mice follow me into the air. (p. 37)

CG: Thanks David. I read these two poems several times over because of where they took me in my thinking and imagining...almost Koan-like and I think very much related to this work. Timely for me too...just got word two days ago that my Sensei in Japan is dying...been thinking about flying there to say goodbye but it is not the Japanese way, though I have been told he would like to see me. He is at home, in his bed most of the time...stomach cancer and it seems the hospital sent him home but he may have wanted to be home as well.

At the end of a letter he wrote the following: "Please do not worry. This is how I am now." Those words have been deeply echoing in me these past two days...brewing, like a yet-to-come eulogy for Sensei on those words which remind me of the poem's line "We are here, we are here."

"This is how I am now".... resolve in the face of and comfort for the still thriving... Indeed, sensei's resolve is inherently the way of the warrior. He is comported for what has been coming all along, and is now so near. Quoting Kawabata Ryu (in Niwa \& Wilson, 2012, p. xviii):

When the doctor

gives up, the tengu [demon]

is called.

Oh it makes me so sad at once.

DJ: Yes, let yourself go to this spot. Reminds me of this old thing that Gary Snyder (1990) cites from Dong-Shan, a 9th century Chan/Zen Master:

One time when the Master was washing his bowls, he saw two birds contending over a frog. A monk who also saw this asked, "Why does it come to that?" The Master replied, "It's only for your benefit." (p. 175)

GM: And it reminds me of the haiku by Issa that he wrote after the death of his infant daughter from smallpox (Hass, 1994, p. 228):

The world of dew

is the world of dew.

And yet, and yet.

CG: These bring to another level my experiences with obanami while I lived in Japan. Cherry blossom parties under the trees... Some of my fondest memories are of these gatherings with friends and family... Like dewdrops... And brilliant in their radiance... Fleeting as they were.... Thanks fellas...

DJ: Ted Aoki would often refer to his daughter who died quite young as a cherry blossom - beautiful, fragrant, yet not lasting long. Fleeting. Like dew. He and I did a presentation at the University of Victoria years and years ago called "The Cherry Blossom and the Rose" to highlight the European pursuit of "the 
lasting" and the Japanese sense of ephemeralness. It's why I love this Don Domanski (2002) passage in an old interview:

... what the Japanese refer to as "the slender sadness," that runs through every moment of existence, about the fleetingness of lives lived in a world where nothing can be saved. [It is] entering that state of being with a joy and wonder that comes from that very impermanency, from the absolute dispossession of everything we love and cherish. The wonder is that anything at all exists. The joy is that it does, even if it is as momentary as a human life. We can live this as a mode of attention, we can live within its movements, its cycles and treasure the phases, the round of it. (p. 246)

\section{Coda to Four Fragments}

Our work continues. The three of us have often shared an anecdote from years ago, a little happenstance in the midst of practicum supervision in a Grade One class. The children were agonizing over written letters in their journals, with the sore hot spot on your finger that grows from a sweaty, too-tight grip of a pencil.

"Do you know why you are having so much trouble learning to write?"

Silence, as faces looked up in anticipation.

"Because it is hard to do." With palpable relief, everyone got back to the task at hand, now freed from and for the difficulties to come.

\section{References}

Berry, W. \& Moyers, B. (2013). Writer and farmer Wendell Berry on hope, direct action, and the "resettling" of the American countryside. Posted October 11, 2013 on-line in Yes Magazine. Accessed November 22, 2013 at: http://www.yesmagazine.org/planet/mad-farmer-wendell-berry-gets-madder-in-defenseof-earth.

Domanski, D. (1998). Parish of the physic moon. Toronto: McClelland \& Stewart.

Domanski, D. (2002). The wisdom of falling. In T. Bowling (Ed.), Where the words come from Canadian poets in conversation (pp. 244-255). Roberts Creek, British Columbia, Canada: Nightwood Editions.

Eliade, M. (1968). Myth and reality. New York: Harper \& Row.

Gadamer, H.G. (1986). The idea of the University - Yesterday, today, tomorrow. In D. Misgeld $\quad$ \& $\quad$ G. Nicholson (Eds. and Trans.), Hans-Georg Gadamer on education, poetry, and history: Applied hermeneutics (pp. 47-62). Albany NY: SUNY Press.

Gadamer, H.G. (1989). Truth and method. New York: Continuum Books.

Gadamer, H.G. (1994). Heidegger's ways. Boston: MIT Press.

Hass, R. (Ed.). (1994). The essential baiku: Versions of Basho, Buson, \& Issa. Hopewell, NJ: Ecco.

Heidegger, M. (1963). Being and time. New York: Harper and Row.

Husserl, E. (1970). The crisis of European science and transcendental phenomenology. Evanston IL: Northwestern University Press.

Innes, J. (in press a). Time. In D. Jardine, G. McCaffrey \& C. Gilham (Eds.), On the pedagogy of suffering: Hermeneutic and Buddhist meditations. New York: Peter Lang Publishers.

Innes, J. (in press b). A pocket of darkness. In D. Jardine, G. McCaffrey \& C. Gilham (Eds.), On the pedagogy of suffering: Hermeneutic and Buddhist meditations. New York: Peter Lang Publishers

Jardine, D. (2012). Pedagogy left in peace: On the cultivation of free spaces in teaching and learning. New York: Bloomsbury Publishing.

Kearney, R. (2011). What is diacritical hermeneutics? Journal of Applied Hermenentics. Accessed on line August 18, 2013 at: http://jah.synergiesprairies.ca/jah/index.php/jah/article/download/6/7

McCaffrey, G. (in press). Idiot compassion. In D. Jardine, G. McCaffrey \& C. Gilham. On the pedagogy of suffering: Hermeneutic and Buddhist meditations. New York: Peter Lang Publishers. 
Niwa, C., \& Wilson, W. S. (2012). The demon's sermon on the martial arts: And other tales. Boston: Shambhala.

Saint Jerome (1964). Homily 40: On psalm 115 (116B). In The homilies of Saint Jerome (Vol. 1), (1-59 On the psalms) (pp. 293-299). The fathers of the church \#48. Washington, D.C.: The Catholic University of America Press.

Snyder, G. (1990). Survival and sacrament. In The practice of the wild (pp. 175-185). Berkley CA: Counterpoint Books.

Trungpa. C. (2003). The myth of freedom and the way of meditation. In C. Trungpa, The collected works of Chogyam Trungpa (Vol. 3). Boston: Shambala Press.

Tsong-kha-pa (2000). The great treatise on the stages of the path to enlightenment (Vol. 1). Ithaca NY: Snow Lion Publications.

Tsong-kha-pa (2002). The great treatise on the stages of the path to enlightenment (Vol. 3). Ithaca NY: Snow Lion Publications.

Tsong-kha-pa (2004). The great treatise on the stages of the path to enlightenment (Vol. 2). Ithaca NY: Snow Lion Publications.

\section{About the Authors}

David W. Jardine is a Professor of Education in the Werklund School of Education, University of Calgary. He is the co-author, with Jackie Seidel, of the forthcoming text Ecological Pedagogy, Buddhist Pedagogy, Hermeneutic Pedagogy: Experiments in a Curriculum for Miracles, and can be reached at jardine@ucalgary.ca

Graham McCaffrey is an Assistant Professor in the Faculty of Nursing, University of Calgary, and can be reached atgpmccaff@ucalgary.ca

Christopher Gilham is an Assistant Professor of Education in the Faculty of Education, St. Francis Xavier University, and can be reached at cmgilham@ucalgary.ca 